\title{
Inheritance of flower traits in ornamental pepper ${ }^{1}$
}

\author{
Angela Maria dos Santos Pessoa²; Elizanilda Ramalho do Rêgo ${ }^{3}$; Cristine Agrine Pereira dos Santos ${ }^{4}$; \\ Michelle Gonçalves de Carvalho ${ }^{5}$; Júlio Carlos Polimeni de Mesquita ${ }^{6}$; Mailson Monteiro do Rêgo ${ }^{7}$
}

\begin{abstract}
Diallel crosses provide estimates of useful parameters in the selection of parents for hybridization. They also help in understanding the gene action behind the determination of characters of interest. The objective of this study was to determine the genetic control of flower traits in ornamental pepper based on a complete diallel with parents F1's and reciprocal crosses. The experiment was conducted in a greenhouse at Laboratório de Biotecnologia Vegetal, Centro de Ciências Agrárias, Universidade Federal da Paraíba (CCA-UFPB). Seven accessions of ornamental pepper belonging to the CCA-UFPB Germplasm Bank UFPB001, UFPB004, UFPB77.3, UFPB099, UFPB134, UFPB137 and UFPB390 were used. The morphological analysis was performed on following quantitative Capsicum descriptors: days for flowering (DFL), flower diameter (FD), petal length (PL), number of petals (NP), number of stamens (NS), anther length (AL) and fillet length (FL). The data were previously submitted to analysis of variance and then to diallel analysis. All evaluated traits were adequate to the additive-dominant model. There are possibilities of genetic gains in breeding programs, for the NP, NS, AL and FL in ornamental peppers.
\end{abstract}

Keywords: Capsicum annuum; genetic control; hybridization.

\section{Herança para características de flor em pimenteira ornamental}

Resumo: Os cruzamentos dialélicos propiciam estimativas de parâmetros úteis na seleção de genitores para hibridação e no entendimento da ação gênica envolvida na determinação dos caracteres de interesse. Assim objetivou-se neste trabalho determinar o controle genético das características de flor em pimenteiras ornamentais com base em dialelo completo, com pais, $\mathrm{F}_{1}$ 's e recíprocos. $\mathrm{O}$ experimento foi conduzido em casa de vegetação no setor de Biotecnologia Vegetal do Centro de Ciências Agrárias, Universidade Federal da Paraíba (CCA-UFPB). Foram utilizados sete acessos de pimenteira ornamental, pertencentes ao Banco de Germoplasma da CCA-UFPB: UFPB001, UFPB004, UFPB77.3, UFPB099, UFPB134, UFPB137 e UFPB390. A caracterização morfoagronômica foi realizada com base nos descritores de Capsicum, sendo avaliadas dias para floração (DFL), diâmetro da flor (DF), comprimento das pétalas (CP), número de pélatas (NP), número de estames (NE), comprimento da antera (CA) e comprimento do filete (CF), características quantitativas referentes à flor. Os dados foram previamente submetidos à análise de variância e, posteriormente à análise dialélica. Todas as características avaliadas se adequaram ao modelo aditivo-dominante. Há possibilidades de ganhos genéticos para NP, NE, CA e $\mathrm{CF}$ em pimenteiras ornamentais.

Palavras-chave: Capsicum annuum; controle genético; hibridação.

\footnotetext{
${ }^{1}$ Submetido em 10/01/2018 e aprovado em 12/04/2018

${ }^{2}$ Doutora em Agronomia; Bolsista PNPD, Universidade Federal da Paraíba (UFPB), Centro de Ciências Agrária, Programa de Pós-Graduação em Agronomia, Areia-PB, CEP: 58397-000; E-mail: angelapessoapb@gmail.com

${ }^{3}$ Doutora em Genética e Melhoramento; Professora Associada, Universidade Federal da Paraíba (UFPB), Centro de Ciências Agrária, Departamento de Ciências Fundamentais e Sociais, Areia-PB, CEP: 58397-000; E-mail: elizanilda@cca.ufpb.br

${ }^{4}$ Mestre em Agronomia; Doutoranda, Universidade Federal da Paraíba (UFPB), Centro de Ciências Agrária, Programa de Pós-Graduação em Agronomia, Areia-PB, CEP: 58397-000; E-mail: cristineagrine.ps@ @otmail.com

${ }^{5}$ Mestre em Agronomia; Doutoranda, Universidade Federal da Paraíba (UFPB), Centro de Ciências Agrária, Programa de Pós-Graduação em Agronomia, Areia-PB, CEP: 58397-000; E-mail: carvalho.areia@hotmail.com

${ }^{6}$ Doutor em Agronomia; Engenheiro Agronômo, Instituto Agronômico de Pernambuco (IPA), Recife-PE; E-mail: jcpmesquita@ yahoo.com.br ${ }^{7}$ Doutor em Genética e Melhoramento; Professor Adjunto III, Universidade Federal da Paraíba (UFPB), Centro de Ciências Agrária, Departamento de Ciências Biológicas, Areia-PB, CEP: 58397-000; E-mail: mailson@cca.ufpb.br
} 


\section{Introdution}

Peppers of the genus Capsicum are rich in vitamins $\mathrm{A}, \mathrm{C}$ and $\mathrm{E}$ and present genetic diversity for several traits (Rêgo et al. 2012a). Its fruits have several compounds including carotenoids, flavonoids and essential mineral elements, as well as Capsaicin (Stommel and Bosland, 2008). Due to these characteristics, they are part of the formulation of pharmaceuticals and cosmetics, and are used as raw material for pepper spray (Neitzke et al., 2016). Pepper plants are also used as ornamental in interior and landscape design (Rêgo et al., 2011; Rêgo and Rêgo, 2016).

Flowers that stand out among foliage are of interest in ornamental peppers, as they provide beauty to the plant making them more attractive to consumers (Santos et al., 2013). This feature also facilitates the process of emasculation and manual crossing in breeding programs (Santos et al., 2013; Nascimento et al., 2013).

The inheritance of a trait is the transmission of genetic information to the offspring and that can be studied through genetic parameters obtained from controlled crosses (Baldissera et al., 2014), such as diallel crosses.

Diallel crosses provide estimates of useful parameters in the selection and understanding of the gene action involved in character (Cruz et al., 2012).

Among the various methods proposed for the analysis of diallel crosses, the Hayman method (Hayman, 1954a) provides information about important genetic parameters such as the average degree of dominance and number of genes (Vivas et al., 2013). In this context, the objective of this study was to determine the inheritance of flower characteristics in ornamental peppers based on complete diallel cross, with parents, F1's and reciprocal.

\section{Material and Methods}

The experiment was carried out in a greenhouse at the Laboratório de Biotecnologia Vegetal, Centro de Ciências Agrárias, Universidade Federal da Paraíba, (CCA-UFPB), Areia, Paraíba State, Brazil.

Seven accessions of ornamental pepper $(C$. annuит L.) belonging to the Germplasm Bank of the CCA-UFPB: UFPB001, UFPB004, UFPB77.3, UFPB099, UFPB134, UFPB137 and
UFPB390 were used.

Manual crosses were performed on flower buds, pre-anthesis, based on complete diallel, with parents, $F_{1}$ 's and reciprocals.

The seeds of the 42 hybrids and seven parental were sown in polystyrene trays of 128 cells filled with commercial substrate (Plantmax ${ }^{\circledR}$ ) and when they presented six definitive leaves, were transplanted into a plastic vessel containing 900 $\mathrm{mL}$ of the same substrate.

The morphoagronomic characterization was performed based on the Capsicum descriptors (IPGRI, 1995). Seven quantitative characters related to the flower were evaluated. Flower data were collected when they were fully open and during the first flowering. The flower characteristics evaluated were: Days for Flowering (DFL), Flower Diameter (FD), Petal Length (PL), Number of Petals (NP), Number of Stamens (NS), Antera Length (AL) and Fillet Length (FL). To obtain data on the dimensions, a digital caliper was used (Leetools ${ }^{\circledR}$ digital caliper) and the quantity values were taken by counting.

The experimental design was completely randomized, with 49 treatments, which consisted of 42 hybrids and seven parents, with eight replicates. Each repetition consisted of a vase with a plant. Genetic variability was detected through analysis of variance, with $\mathrm{F}$ test, at 5\% probability.

For application of methodology proposed by Hayman (1954a), modified by Viana et al. (1999), it was necessary to test if the flower traits fulfilled the following assumptions: Mendelian inheritance and homozygous parents, absence of reciprocal effect, epistatic interactions and multiple alelism. In addition, genes must be randomly distributed between parents. These requirements were verified by the additivedominant model adequacy test as follows: the values of $\mathrm{Wi}$ and $\mathrm{Vi}$ were used to test the data by adjusting the additive-dominant model by: a) the variation of $\mathrm{Wi}$ - Vi was evaluated by analysis of variance, testing the occurrence of differences in the values of this expression between the lines of the crossed matrix; b) linear regression analysis of Wi in $\mathrm{Vi}$, testing the significance of the angular coefficient of the straight line (HO: $b=1$ vs Ha: $b$ $\neq 1)$; c) weighting Wi and $\mathrm{Vi}$ by $45^{\circ}$ of rotation of the axes represented by these statistics, and with 
the new values of $\mathrm{Wi}$ and $\mathrm{Vi}$, the angular coefficient of the straight line was tested after the rotation ( $\mathrm{H} 0: b=0$ vs $\mathrm{Ha}: \mathrm{b} \neq 0)$.

After verifying the adaptation of the data to the additive-dominant model, the interpretation of the analysis of variance and the statistics obtained from the diallelic table were used to estimate the genetic and environmental components: E (Environmental variance effects); D - (Additives of genes); $\mathrm{H}_{1}, \mathrm{H}_{2}$ and $\mathrm{h}_{2}$ (Effects due to dominance); F - (Effect of covariance between additive and non additive effect) and $\mathrm{D}-\mathrm{H}_{1}$ (Component expressing the difference between the additive and dominant gene effects).

Estimates of the genetic components of the variation were divided by standard deviation and the significance was determined by $\mathrm{t}$ test $(\mathrm{p} \leq 0.05)$ (Singh and Chaudhary, 1979).

The following genetic parameters were also estimated: $\sqrt{\mathrm{H}_{1}} / \mathrm{D}$ (Mean degree of dominance); $\mathrm{H}_{2} / 4 \mathrm{H}_{1}$ (allele distribution among parents (symmetry), with a maximum value of 0.25 ); dominant and recessive relationship; number of genes with dominance; narrow coefficient of determination; broad coefficient of determination; correlation between the average values of the parents ( $\hat{Y} i i)$; sum of covariance, between parent means and r-line averages $(\hat{\mathrm{Wr}})$; variance between means of the rth line $(\hat{V} r)$; expected values of the $\hat{\mathrm{W}} \mathrm{r}, \hat{V} R$ and $\hat{\mathrm{WD}}$ coordinates, $\hat{V} R$ and predicted value for the parent with maximum concentration of dominant alleles ( $\hat{Y} R$ ) and recessive ( $\hat{Y}$ ) alleles. The meaning of the components and parameters is explained by Hayman (1954b). All analyses were performed using the Genes computational program (Cruz, 2013).

\section{Results and Discussion}

There were a significant differences among the treatments $(\mathrm{p} \leq 0.05)$ for all evaluated characteristics (Table 1). The significance indicates the existence of genetic variability among the evaluated genotypes and allows the inclusion of these characters in genetic breeding studies (Medeiros et al. 2014: Streck et al., 2017).

Table 1 Analysis of variance and estimates of the quadratic components for flower traits in ornamental pepper (Capsicum annuum L.)

\begin{tabular}{|c|c|c|c|c|c|}
\hline \multirow{2}{*}{ Source of variation } & \multirow{2}{*}{ GL } & \multicolumn{4}{|c|}{ Mean Square } \\
\hline & & DFL & $\mathrm{DF}$ & PL & NP \\
\hline Trataments & 48 & $86.259 * *$ & $0.158 * *$ & $0.020 * *$ & $0.480 * *$ \\
\hline Resídual & 343 & 8.399 & 0.056 & 0.007 & 0.126 \\
\hline \multirow{2}{*}{\multicolumn{2}{|c|}{$\begin{array}{c}\text { Overall Mean } \\
\text { CV }(\%)\end{array}$}} & 29.650 & 1.678 & 0.478 & 5.498 \\
\hline & & 9.775 & 12.981 & 18.924 & 6.197 \\
\hline \multirow{2}{*}{ Source of variation } & \multirow{2}{*}{ GL } & \multicolumn{4}{|c|}{ Mean Square } \\
\hline & & NS & & & FL \\
\hline Trataments & 48 & $0.456 * *$ & & & $0.009 * *$ \\
\hline Resídual & 343 & 0.107 & & & 0.003 \\
\hline Overall Mean & & 5.488 & & & 0.462 \\
\hline CV $(\%)$ & & 5.960 & & & 11.862 \\
\hline
\end{tabular}

The coefficients of variation (CV) ranged from $5.960 \%$ (NS) to $20.008 \%$ (AL) (Table 1). In peppers, CV values vary according to the characteristic, genotype and species under study (Silva et al., 2011).

None of the studied variables presented significant effects of regression coefficients
(Table 2). The absence of significance of the regression coefficients in the sufficiency test of the additive-dominant model indicates homogeneity between the variances and covariance, which is in accordance with the constraints imposed by the model and allows the progression to the next step of the analysis. 
Table 2 Test of sufficiency of the additive - dominant model for the flower characters in ornamental pepper (Capsicum annuum L.)

\begin{tabular}{|c|c|c|c|c|c|c|}
\hline \multirow[b]{2}{*}{ Traits } & \multirow[b]{2}{*}{$\begin{array}{c}\text { MS } \\
\text { Regression }\end{array}$} & \multirow[b]{2}{*}{$\begin{array}{c}\text { MS } \\
\text { Deviation }\end{array}$} & \multicolumn{2}{|c|}{ Regression $\mathrm{W}_{\mathrm{i}}=\mathrm{a}+\mathrm{b} \mathrm{V}_{\mathrm{i}}$} & \multirow{2}{*}{$\begin{array}{c}\mathrm{T} \text { valor and } \\
\text { Significance } \\
\left(\mathrm{H}_{0}: \beta=0\right) \text { affter } \\
\text { rotation }\end{array}$} & \multirow[b]{2}{*}{$\begin{array}{l}\text { Fit to } \\
\text { model }\end{array}$} \\
\hline & & & $\begin{array}{c}\text { Intercept (a) } \\
\text { Estimate (DP) }\end{array}$ & $\begin{array}{c}\text { Coeff. Linear } \\
\left(\mathrm{H}_{0}: \beta=1\right) \\
\text { F Estimate (DP) }\end{array}$ & & \\
\hline DFL & $66.226^{\mathrm{ns}}$ & 12.807 & $2.722(2.149)$ & $0.565(0.248)^{\mathrm{ns}}$ & $0.748^{\mathrm{ns}}$ & Adequate \\
\hline DF & $0.001 * *$ & 0.000 & $0.007(0.002)$ & $1.171(0.147)^{\mathrm{ns}}$ & $-1.633^{\mathrm{ns}}$ & Adequate \\
\hline $\mathbf{C P}$ & $0.001 *$ & 0.000 & $0.001(0.000)$ & $1.201(0.176)^{\mathrm{ns}}$ & $-1.693^{\mathrm{ns}}$ & Adequate \\
\hline NP & $0.003 * *$ & 0.000 & $0.008(0.005)$ & $1.009(0.114)^{\mathrm{ns}}$ & $-0.368^{\mathrm{ns}}$ & Adequate \\
\hline NE & $0.002 * *$ & 0.000 & $0.009(0.004)$ & $1.019(0.118)^{\mathrm{ns}}$ & $-0.465^{\mathrm{ns}}$ & Adequate \\
\hline CA & $0.000^{\mathrm{ns}}$ & 0.000 & $0.000(0.000)$ & $0.213(0.499)^{\mathrm{ns}}$ & $-0.292^{\mathrm{ns}}$ & Adequate \\
\hline $\mathbf{C F}$ & 0.000 & 0.000 & $-0.000(0.000)$ & $0.824(0.197)^{\mathrm{ns}}$ & $0.319^{\mathrm{ns}}$ & Adequate \\
\hline
\end{tabular}

DFL - Dias para floração; DF - Diâmetro da flor; CP - Comprimento da pétala; NP - Número de pétalas; NE - Número de estames; CA - Comprimento da antera e CF - Comprimento do filete. ${ }^{n}$ não significativo, ${ }^{*} \mathrm{e} * *$ significativo, em nível de 5 e 1 $\%$ de probabilidade, respectivamente.

The correlations $\mathrm{r}(\hat{W} i+\hat{V i}$ and $\hat{Y i i})$ were positive for the DFL, FD, PL, NP, NS and AL characteristics and negative only for the FL variable (Table 3 ). This fact evidences that the recessive alleles are the ones that increase most of the characteristics, except for fillet length (FL).

For DFL, the limits of selection are 65.840 in the most recessive genotype and 28.845 in the most dominant genotype. The parents who presented the highest number of recessive alleles were UFPB77.3 and UFPB390, with values of $\hat{W} i+\hat{V} i$ equal to 30.507 and 19.511 , respectively (Table 3). In contrast, UFPB099 (2.029), UFPB004 (6.597) and UFPB137(7.491) (Table 3 and Figure 1a) showed higher concentration of dominant alleles. It is noteworthy that for this variable the selection must lean towards dominant alleles, since the selection limit for earlier plants was 28.845, and among the parents the UFPB001 already has an average lower than the selection limit (17.257).

For the FD variable, the parents who presented the highest number of recessive alleles were UFPB004 and UFPB001, with $\hat{W} i+\hat{V} i$ values equal to 0.04 and 0.039 , respectively (Table 3 ). In contrast, parents UFPB (0.016) and UFPB134 (0.022) had higher concentrations of dominant alleles (Table 3 and Figure 1a). The UFPB099 parent already has an average above the selection limit for flower diameter (1.92) (Table 3 and Figure 1b).

The selection limits for PL were 0.496 for the most recessive accession and 0.428 for the most dominant accession. Those accessions are UFPB001, UFPB099 and UFPB004, with values of $0.505,0.523$ and 0.567 , respectively (Table 3, Figure 1c).

For NP, the parents with the highest $\hat{W} i+\hat{V} i$ values were UFPB001 (0.138), UFPB004 (0.121) and UFPB099 (0.120) (Table 3, Figure 1d). The selection limits for this characteristic are 5.976, in the most recessive parent and 5.049 in the dominant. The parent with the highest number of petals was UFPB001, which was below the selection limit, indicating that it is possible to select superior lineages from the populations of these crosses for this variable.

As for NS, UFPB001 and UFPB099 as parents had the highest concentrations of recessive alleles (Table 3 and Figure 1e) with $\hat{W} i+\hat{V i}$ values of 0.132 and 0.103 , respectively. It is possible to select, in the segregating generations of this diallel, plants with flowers with greater number of stamens.

The UFPB001 parents had a higher concentration of recessive alleles for AL, with a value of 0.05 (Table 3 and Figure 1f). It is possible to select plants with larger anthers in segregating generations.

Several authors have reported the importance of selection of floral components, such as corolla length, petal diameter, anther, fillet and stylet length, number of petals and stamens, in pepper intended for ornamentation both in pots and in different stratum of landscape design 
(Nascimento et al., 2012, Santos et al 2014, Silva Neto et al., 2014, Ferreira et al., 2015). In addition to the previously cited authors, Santos et al. (2013), Rêgo et al. (2015) and Silva et al. (2017), emphasized the importance of the flower length and width variables in selection of ornamental peppers in pots. Breeders should focus their research on the most important characters depending on the ideotype (Rêgo e Rêgo, 2018).

Table 3 Parameters estimated in the diallel, by the Hayman method (1954) for flower characteristics in ornamental pepper (Capsicum annuum L.)

\begin{tabular}{|c|c|c|c|c|c|c|c|c|}
\hline \multirow{2}{*}{ Accessions } & \multicolumn{2}{|c|}{ DFL } & \multicolumn{2}{|c|}{$\mathrm{FD}(\mathrm{cm})$} & \multicolumn{2}{|c|}{$\mathrm{PL}(\mathrm{cm})$} & \multicolumn{2}{|c|}{ NP } \\
\hline & Mean & $\hat{W} i+\hat{V} i$ & Mean & $\hat{W} i+\hat{V} i$ & Mean & $\hat{W} i+\hat{V} i$ & Mean & $\hat{W} i+\hat{V} i$ \\
\hline UFPB001 & 17.257 & 17.257 & 1.843 & 0.039 & 0.505 & 0.004 & 5.8333 & 0.138 \\
\hline UFPB004 & 31.000 & 6.597 & 1.853 & 0.040 & 0.567 & 0.004 & 5.666 & 0.121 \\
\hline UFPB77.3 & 39.875 & 30.507 & 1.287 & 0.034 & 0.355 & 0.003 & 5.125 & 0.050 \\
\hline UFPB099 & 28.875 & 2.029 & 1.920 & 0.033 & 0.523 & 0.002 & 5.875 & 0.120 \\
\hline UFPB134 & 31.875 & 9.302 & 1.598 & 0.022 & 0.464 & 0.005 & 5.333 & 0.079 \\
\hline UFPB137 & 30.375 & 7.491 & 1.602 & 0.016 & 0.430 & 0.004 & 5.333 & 0.018 \\
\hline UFPB390 & 38.500 & 19.511 & 1.520 & 0.036 & 0.371 & 0.003 & 5.166 & 0.043 \\
\hline$r(\hat{Y} i i, \hat{W i}+\hat{V i})$ & \multicolumn{2}{|c|}{0.717} & \multicolumn{2}{|c|}{0.283} & \multicolumn{2}{|c|}{0.141} & \multicolumn{2}{|c|}{0.876} \\
\hline$(\hat{W} R, \hat{V} R)$ & \multicolumn{2}{|c|}{ (39.896. 65.779) } & \multicolumn{2}{|c|}{$(0.033 .0 .022)$} & \multicolumn{2}{|c|}{$(0.004 .0 .003)$} & \multicolumn{2}{|c|}{$(0.087 .0 .078)$} \\
\hline$(\hat{W} D, \hat{V} D)$ & \multicolumn{2}{|c|}{$(2.921 .0 .352)$} & \multicolumn{2}{|c|}{$(0.009 .0 .001)$} & \multicolumn{2}{|c|}{$(0.001 .0 .001)$} & \multicolumn{2}{|c|}{$(0.007 .0 .008)$} \\
\hline $\begin{array}{l}\text { Prediction } \\
\text { equation }\end{array}$ & \multicolumn{2}{|c|}{$\begin{aligned} \hat{Y} \boldsymbol{i}= & 27.662+0.361 \\
& (\hat{W} i+\hat{V} i)\end{aligned}$} & \multicolumn{2}{|c|}{$\begin{aligned} \hat{Y} \boldsymbol{i}= & 1.430+7.196 \\
& (\hat{W} i+\hat{V} i)\end{aligned}$} & \multicolumn{2}{|c|}{$\begin{array}{c}\hat{Y} \boldsymbol{i}=0.417+10.746 \\
(\hat{W} i+\hat{V} i)\end{array}$} & \multicolumn{2}{|c|}{$\begin{aligned} \hat{Y} \boldsymbol{i}= & 4.991+5.930 \\
& (\hat{W} i+\hat{V} i)\end{aligned}$} \\
\hline$\hat{Y R}$ Limit & \multicolumn{2}{|c|}{65.840} & \multicolumn{2}{|c|}{1.836} & \multicolumn{2}{|c|}{0.496} & \multicolumn{2}{|c|}{5.976} \\
\hline$\hat{Y} D$ Limit & \multicolumn{2}{|c|}{28.845} & \multicolumn{2}{|c|}{1.510} & \multicolumn{2}{|c|}{0.428} & \multicolumn{2}{|c|}{5.049} \\
\hline \multirow{2}{*}{ Accessions } & & S & & $\mathrm{AL}(\mathrm{cm}$ & & & FL $(\mathrm{cm})$ & \\
\hline & Mean & $\hat{W} i+\hat{V} i$ & & ean & $\hat{W} i+\hat{V}_{i}$ & Mean & & $+\hat{V i}$ \\
\hline UFPB001 & 5.833 & 0.132 & & 252 & 0.005 & 0.414 & & 01 \\
\hline UFPB004 & 5.625 & 0.099 & & 245 & 0.003 & 0.422 & & 008 \\
\hline UFPB77.3 & 5.125 & 0.053 & & 211 & 0.004 & 0.396 & & 02 \\
\hline UFPB099 & 5.833 & 0.103 & & 248 & 0.004 & 0.431 & & 001 \\
\hline UFPB134 & 5.291 & 0.084 & & 268 & 0.004 & 0.462 & & 008 \\
\hline UFPB137 & 5.333 & 0.020 & & 234 & 0.001 & 0.525 & & 001 \\
\hline UFPB390 & 5.125 & 0.0474 & & 218 & 0.001 & 0.437 & & 001 \\
\hline$r(\hat{Y} i i, \hat{W i}+\hat{V i})$ & & 305 & & 0.387 & & & -0.057 & \\
\hline$(\hat{W} R, \hat{V} R)$ & $(0$. & $0.072)$ & & $(0.001 .0$. & & & 002.0 .00 & \\
\hline$(\hat{W} D, \hat{V} D)$ & $(0$. & 0.001) & & (0.001.0. & & & 003.0 .00 & \\
\hline $\begin{array}{l}\text { Prediction } \\
\text { equation }\end{array}$ & $\hat{Y} i=$ & $\begin{array}{l}3+6.460 \\
+\hat{V i})\end{array}$ & & $\begin{aligned}= & 0.223+ \\
& (\hat{W} i+\hat{V}\end{aligned}$ & 0.896 & & $\begin{array}{l}0.447-3 \\
(\hat{W} i+\hat{V} i)\end{array}$ & \\
\hline$\hat{Y} R$ Limit & & 61 & & 0.718 & & & 0.428 & \\
\hline$\hat{Y D}$ Limit & & 28 & & 0.228 & & & 0.446 & \\
\hline
\end{tabular}

DFL - Days for flowering; FD - Flower diameter; PL - Petal length; NP - Number of petals; NS - Number of stamens; AL - Anther Length and FL - Fillet length.

$\hat{W} i+\hat{V} i$ : Allele concentration, r: correlation coefficient between $\hat{W} i+\hat{V} i$ and $\hat{Y} i i$. Maximum values of dominant $(\hat{W} D, \hat{V} D)$ and recessive homozygosity $(\hat{W} R, \hat{V} R), \hat{Y} R$ and $\hat{Y} D$ : limit of selection order of classification of the parents with concentration of recessive and dominant genes. $\mathrm{cm}$ (centimeter). 

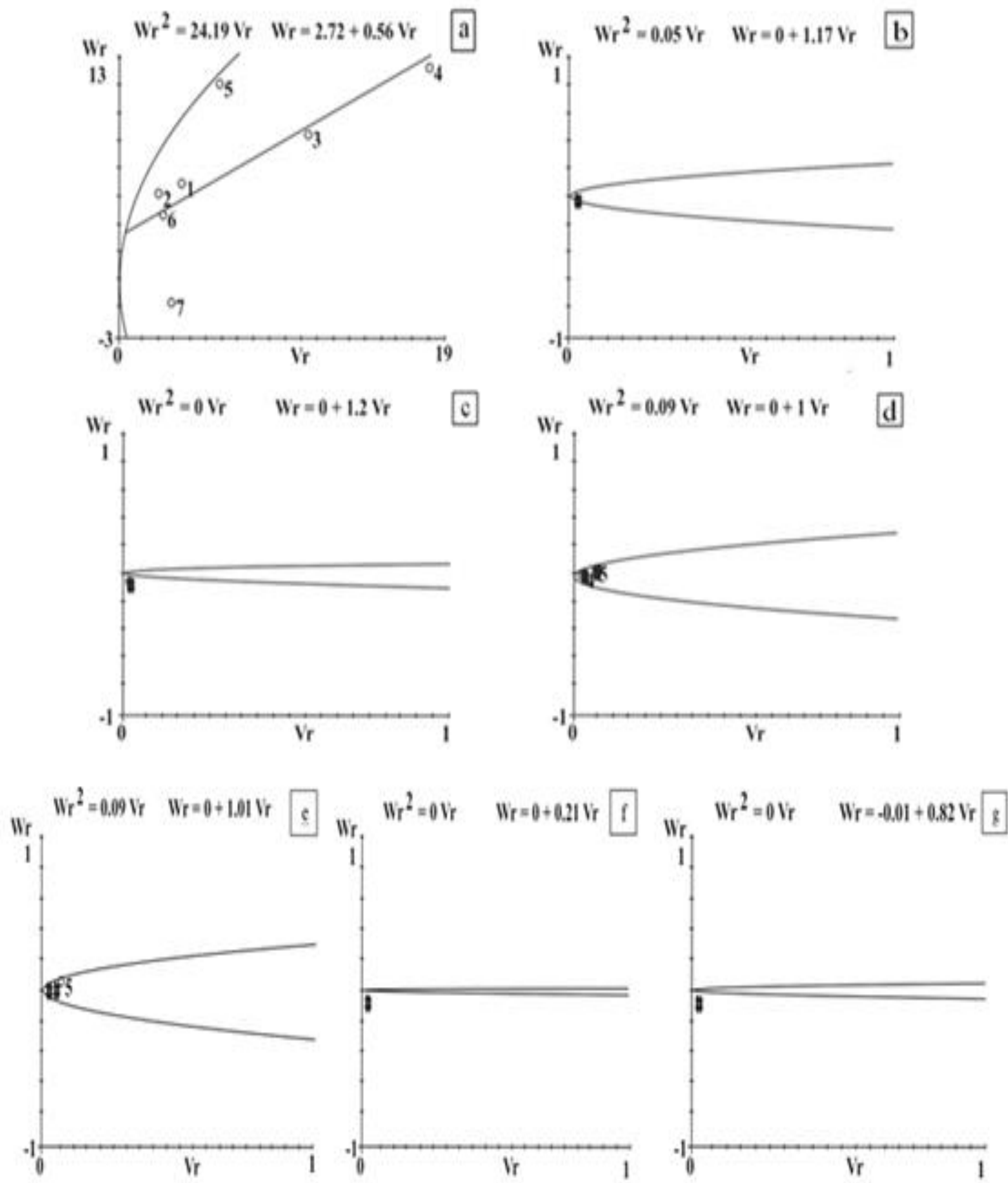

Figure 1 Straight line and parabola established by the relationships between covariance Wi, between means of parent and means within the i-th row, and the variance $\mathrm{Vi}$, between means within the row for the traits of ornamental pepper flowers (Capsicum annuum L.): (a) days for flowering, (b) flower size, (c) length of da pétala, (d) number of petals, (e) number of stamens, (f) anther length and (g) fillet length. Parents: $\mathbf{1}=$ UFPB134, $2=$ UFPB137, 3 = UFPB390, 4 = UFPB77.3, 5 = UFPB001, $\mathbf{6}=$ UFPB004 and 7 = UFPB099. Straight line established by $\hat{W} i=\hat{a}+\hat{b} \hat{V} i$, and parabola established by $\hat{W} i^{2}=\hat{V} p \hat{V} i$. 
Table 4. Estimates of genetic parameters of variation due to the additive effects of genes (D), due to dominance $\left(\mathrm{H}_{1}, \mathrm{H}_{2}\right.$ and $\left.\mathrm{h}_{2}\right)$, the effect of covariance between additive and non-additive $(\mathrm{F})$ and environmental $(\mathrm{E})$ effects of diallel related to seven flower traits in ornamental pepper (Capsicum annuит L.)

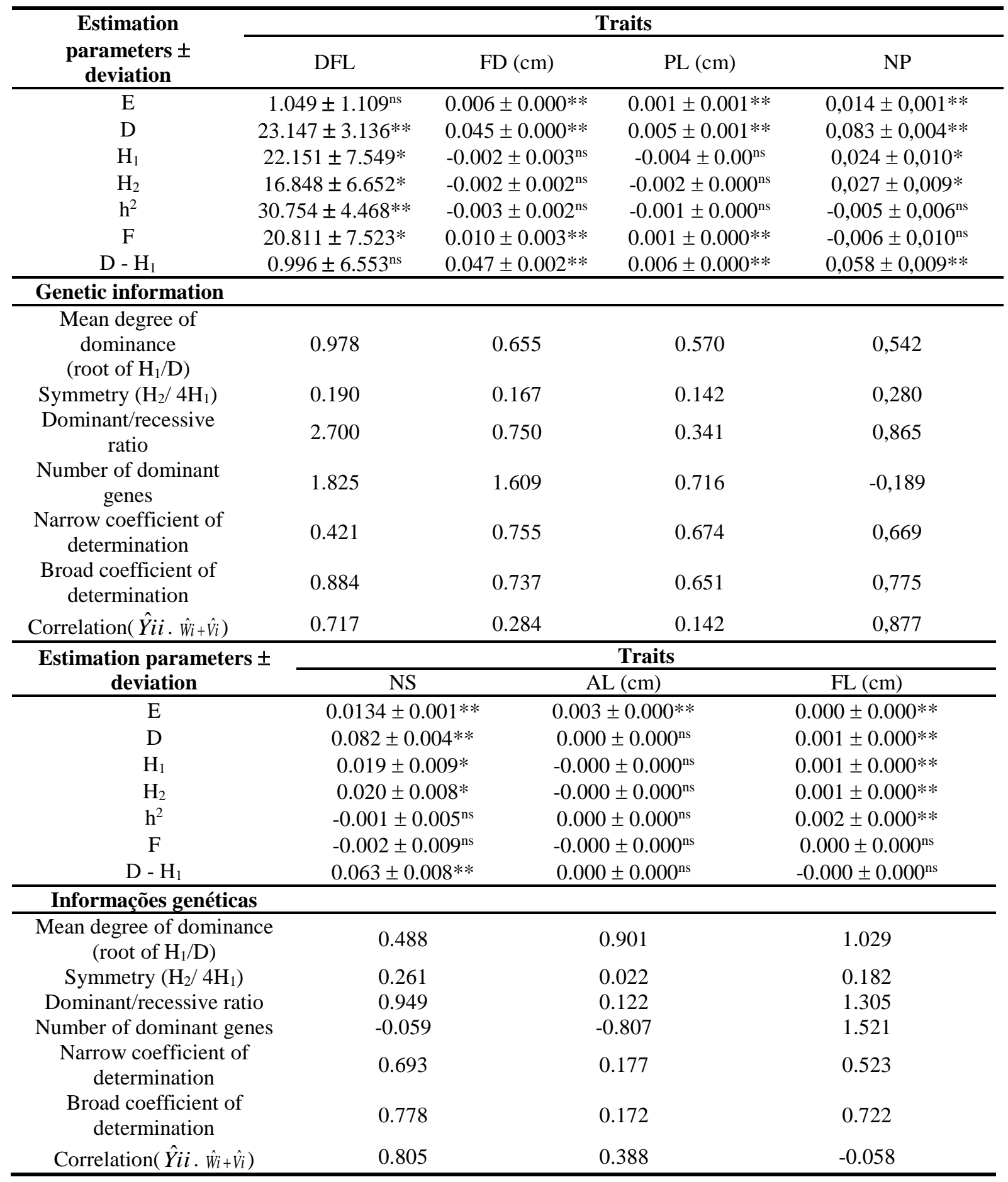

The importance of selection for precocity in ornamental peppers was reported by Rego et al $(2012 b, c)$. The segregating generations obtained in this work constitute single material where the selection for some of these components can be practiced with greater probability of genetic 
gains.

The genetic components of variation, due to the additive effects of the genes (D), were significant at the $1 \%$ probability level by the $t$ test for DFL, FD, PL, NP, NS and FL. The effects of dominance $\left(\mathrm{H}_{1}\right.$ and $\left.\mathrm{H}_{2}\right)$ were significant at $5 \%$ probability for DFL, NP, NS and significant at $1 \%$ for FL (Table 4). The estimates indicating the presence of dominance effects by means of D $\mathrm{H}_{1}$ were significant at $1 \%$ and $5 \%$ probability, by the $t$ test, for FD, PL, NP and NS. For the AL characteristic, only the environmental effect (E) was significant (Table 4).

The mean degree of dominance for DFL, FD, PL, AL, NP and NS indicates the existence of partial dominance while FL presented over dominance interaction (Table 4). Both types of allelic interaction allow to differentiate the hybrid from the homozygotes, when compared to the presence of complete dominance. This fact facilitates if one wishes to introduce genes for the FD, PL, NP and NS variables through backcrosses, since it is possible to identify heterozygous and homozygotes without the need of self-fertilization, making possible negative selection of the dominant and, saving time and labor in the breeding program.

The characteristics FD, PL, NP, NS and FL presented high heritability values in the broad and restricted sense, above 0.651 and above 0.523 , respectively (Table 4 ). The heritability values in the restricted sense found in this work, for these variables, indicate that the effects due to the additivity are more influential in their determination. Several authors have reported high values of heritability in the broad sense in ornamental pepper (Nascimento et al., 2012, Silva Neto et al. 2013; Costa et al. 2016; Silva et al. 2016; Naegele et al., 2016; Devi et al. 2017). In recent years, several papers have also reported that heritability in the narrow sense is involved in the determination of quantitative characters of ornamental peppers (Santos et al., 2012, Santos et al., 2004, Silva Neto et al. et al. 2015; Fortunato et al. 2015; Rêgo et al. 2015 and Silva et al. 2017). Ferreira et al. (2015) and Fortunato et al. (2015) determined that only the additive gene effects determine the number of stamens and corolla length traits. On the other hand, Ferreira et al. (2015) determined that the number of petals is determined, for the most part, by dominant effects. Rêgo et al. (2012b) detected dominant effects determining fillet length.
In cases where the predominant effects are additives, selection may be practiced in early generations with a greater chance of genetic gain. Breeding methods based on selection or the backcrossing method will be more effective in these cases (Rêgo et al., 2009, Rêgo et al., 2015, Rêgo et al., 2016).

For those characters with a predominance of gene effects due to dominance, it is indicated the selection in advanced generations or the exploration of hybrids (Rêgo et al., 2009, Rêgo et al., 2015, Fortunato et al. and Rêgo 2016), or selection in advanced generation with the use of more complex methods such as Pedigree or Recurrent Selection (Rêgo et al., 2009, Rêgo et al., 2015, Rêgo and Rêgo 2016).

\section{Conclusion}

It is possible to select, in early segregating generations of the crosses carried out in this work, genotypes with higher number of petals and stamens and with a longer fillet length.

\section{Acknowledgements}

The authors thank the programa de PósGraduação em Agronomia of Universidade Federal da Paraíba. Thanks also to Conselho Nacional de Desenvolvimento Científico e Tecnológico $(\mathrm{CNPq})$ and to Coordenação de Aperfeiçoamento de Pessoa de Nível Superior (CAPES) for their financial assistance (grants).

\section{References}

Baldissera, J. N. C.; Valentini, G.; Coan, M. M. D.; Guidolin, A. F.; Coimbra, J. L. M. Fatores genéticos relacionados com a herança em populações de plantas autógamas. Revista de Ciências Agroveterinárias, v.13, n.2, p.181189 , 2014. http://pesquisa.bvsalud.org/bvsvet/resource/pt/vti-714180

Costa, M. P. S. D.; Rêgo, M. M.; Da Silva, A. P. G.; Rêgo, E. R.; Barroso, P. A. Characterization and genetic diversity of pepper (Capsicum spp) parents and interspecific hybrids. Genetics and Molecular Research, v.15, n.2, p.1-12, 2016. http://doi:10.4238/gmr.15027652

Cruz, C. D.; Regazzi, A. J.; Carneiro, P. C. Métodos biométricos aplicados ao melhoramento genético. $4^{\mathrm{a}}$ ed. Viçosa, UFV. 414p. 2012.

Cruz, C.D. Programa genes (versão Windows): 
aplicativo computacional em genética e estatística. Editora UFV (Universidade Federal de Viçosa), Viçosa. 2013.

Da Silva, A. R.; Nascimento, M.; Cecon, P. R.; Sapucay, M. J.; Rêgo, E. R.; Barbosa, L. A. Path analysis in multicollinearity for fruit traits of pepper. IDESIA (Chile), v.31, n.2, p.55-60, 2013.

https://scielo.conicyt.cl/pdf/idesia/v31n2/art08.pdf.

Devi, A. A.; Singh, N. B.; Singh, M. D. Research Note Classification and characterization of chilli (Capsicum annuum L.) found in Manipur using multivariate analysis. Electronic Journal of Plant Breeding, v.8, n.1, p.324-330, 2017. http://ejplantbreeding.com/index.php?journal=EJPB\&pag e=article\&op=view\&path\%5B\%5D=1298

Ferreira, K. T. C.; Rêgo, E. R.; Rêgo, M. M.; Fortunato, F. L. G.; Nascimento, N. F. F.; Lima, J. A. M. Combining ability for morphoagronomic traits in ornamental pepper. Acta Horticulturae, v.1087, p.187-194, 2015. https://www.actahort.org/books/1087/1087_22.htm

Fortunato, F. L. G.; Rêgo, E. R.; Santos, C .A. P.; Carvalho, M. G. Heritability and genetic parameters for size-related traits in ornamental pepper (Capsicum annuum L.). Acta Horticulturae, v.1087, p. 201-206, 2015. https://www.actahort.org/books/1087/1087_24.htm

Hayman, B. I. The analysis of variance of diallel tables. Biometrics, v.10, n.2, p.235-244, 1954a. http://www.jstor.org/stable/3001877

Hayman, B. I. The theory and analysis of diallel crosses. Genetics, v.39, n.6, p.789-809, 1954b. https://www.ncbi.nlm.nih.gov/pmc/articles/PMC1209689 /pdf/789.pdf

IPGRI. Descriptores para Capsicum (Capsicum spp). Roma: IPGRI, $1995 . \quad 51 \mathrm{p}$. https://www.bioversityinternational.org/fileadmin/user_u pload/online_library/publications/pdfs/345.pdf

Medeiros, A. M.; Rodrigues, R.; Gonçalves, L. S. A.; Sundré, C. P.; Oliveira, H. S.; Santos, M. H. Gene effect and heterosis in Capsicum baccatum var. pendulum. Ciência Rural, v.44, n.6, p.1031-1036, 2014. http://www.scielo.br/pdf/cr/v44n6/a16214cr20121011.pdf

Naegele, R. P., Mitchell, J.; Hausbeck, M. K. Genetic diversity, population structure, and heritability of fruit traits in Capsicum annuum. PloS one, v.11, n.7, e0156969, 2016. https://doi.org/10.1371/journal.pone.0156969
Nascimento, N. F. F.; Nascimento, M. F.; Santos, R. M. C.; Bruckner, C. H.; Finger, F. L.; Rêgo, E. R.; Rêgo, M. M. Flower color variability in double and three-way hybrids of ornamental peppers. Acta Horticulturae, v.100, p.457464, 2013.

https://www.actahort.org/books/1000/1000 64.htm

Nascimento, N. F. F.; Rêgo, E. R.; Nascimento, M. F.; Finger, F. L.; Bruckner, C. H.; Silva Neto, J. J.; Rêgo, M. M. Heritability and variability of morphological traits in a segregating generation of ornamental pepper. Acta Horticulturae, v. 953, p.299-304, 2012. https://doi.org/10.17660/ActaHortic.2012.953.41

Neitzke, R. S.; Fischer, S. Z.; Vasconcelos, C. S.; Barbieri, R. L.; Treptow, R. O. Pimentas ornamentais: aceitação e preferências do público consumidor. Horticultura Brasileira, v.34, n.1, p.102-109, 2016. http://www.scielo.br/pdf/hb/v34n1/1806-9991-hb-34-0100102.pdf

Pessoa, A. M. S.; Barroso, P. A.; Rêgo, E. R.; Medeiros, G. D. A.; Bruno, R.L.A.; Rêgo, M. M. Genetic divergence of physiological-quality traits of seeds in a population of peppers. Genetics and Molecular Research, v.14, n.4, p.12479-12488, 2015. http://www.funpecrp.com.br/gmr/year2015/vol144/pdf/gmr6418.pdf

Rêgo, E. R.; Finger, F. L.; Rêgo, M. M. Consumption of pepper in Brazil and its implications on nutrition and health of humans and animals. In: Salazar MA; Ortega JM (eds). Pepper: nutrition, consumption and health. Nova Sci. Pub. Inc. 1: 159-170, 2012a. https://link.springer.com/chapter/10.1007/978-3-31906532-8_4

Rêgo, E. R.; Rêgo, M. M.; Costa, F. R.; Nascimento, N. F. F.; Nascimento, M. F.; Barbosa, L. A.; Fortunato, F. L. G.; Santos, R. M. C. Analysis of diallel cross for some vegetative traits in chili pepper. Acta Horticulturae, v.937, 2012b. https://www.actahort.org/books/937/937_36.htm

Rêgo, E.R.; Fortunato, F. L. G.; Nascimento, M. F.; Nascimento, N. F. F.; Rêgo, M. M.; Finger, F. L. Inheritance of earliness in ornamental pepper (Capsicum annиum). Acta Horticulturae. v. 961, p. 405-410. 2012c. https://www.actahort.org/books/961/961 53.htm

Rêgo, E. R.; Rêgo, M. M. Genetics and Breeding of Chili Pepper Capsicum spp. In: Rêgo, E.R.; 
Rêgo, M. M.; Finger, F. L. Production and breeding of chilli peppers (Capsicum spp.). Springer International Publishing Switzerland, p.1-129, 2016. https://link.springer.com/chapter/10.1007/978-3-319$06532-84$

Rêgo, E. R.; Rêgo, M. M. Ornamental pepper. In: Van Huylenbroeck, J. Ornamental crops. Springer International Publishing Switzerland, 2018 (in http://www.springer.com/br/book/9783319906973

Rêgo, E. R.; Rêgo, M. M.; Cruz, C. D.; Finger, F. L.; Casali, V. W. D. Phenotypic diversity, correlation and importance of variables for fruit quality and yield traits in Brazilian peppers (Capsicum baccatum). Genetic Resources and Crop, v.58, n.6, p.909-918, 2011. https://link.springer.com/article/10.1007/s10722-0109628-7

Rêgo, E. R.; Rêgo, M. M.; Finger, F. L.; Cruz, C. D.; Casali, V. W. D. A diallel study of yield components and fruit quality in chilli pepper (Capsicum baccatum). Euphytica, v.168, n.2, p.275-287, 2009. https://link.springer.com/article/10.1007/s10681-0099947-y

Rêgo, M. M.; Sapucay, M. J. L. C.; Rêgo, E. R.; Araújo, E. R. Analysis of divergence and correlation of quantitative traits in ornamental pepper (Capsicum spp.). Acta Horticulturae, v. $1087, \quad$ p. $389-394,2015$. https://www.actahort.org/books/1087/1087_52.htm

Santos, R. M. C.; Rêgo, E. R.; Nascimento, M. F.; Nascimento, N. F. F.; Rêgo, M. M.; Borém, A.; Finger, F. L.; Costa, D. S. Ethylene resistance in a $\mathrm{F}_{2}$ population of ornamental chili pepper (Capsicum annuum). Acta Horticulturae, p.433-438, 2013. https://doi.org/10.17660/ActaHortic.2013.1000.60

Santos, R. M. C.; Rêgo, E. R.; Borém, A.; Nascimento, M. F.; Nascimento, N. F. F.; Finger, F. L.; Rêgo, M. M. Epistasis and inheritance of plant habit and fruit quality traits in ornamental pepper (Capsicum annuиm L.). Genetics and Molecular Research, v.13, v.4, p.8876-8887, 2014. http://dx.doi.org/10.4238/2014.October.31.3

Silva, A. R. D.; Rêgo, E. R.; Pessoa, A. M. D. S.; Rêgo, M. M. Correlation network analysis between phenotypic and genotypic traits of chili pepper. Pesquisa Agropecuária Brasileira, v.51, n.4, p. $372-377, \quad 2016$.
http://www.scielo.br/scielo.php?pid=S0100204X2016000400372\&script=sci_abstract\&tlng=pt

Silva, C. Q.; Rodrigues, R.; Bento, C. S.; Pimenta, S. Heterosis and combining ability for ornamental chili pepper. Horticultura Brasileira, v.35, n.3, p. 349-357, 2017. http://www.scielo.br/scielo.php?pid=S010205362017000300349\&script=sci_arttext

Silva Neto, J. J.; Rêgo, E. R.; Nascimento, M. F.; Silva Filho, V. A. L.; Almeida Neto, J. X.; Rêgo, M. M. Variabilidade em população base de pimenteiras ornamentais (Capsicum annuиm L.). Revista Ceres, v.61, n.1, p. 84-89, 2014. http://www.scielo.br/pdf/rceres/v61n1/v61n1a11.pdf

Silva, A. R.; Cecon, P. R.; Rêgo, E. R.; Nascimento, M. Avaliação do coeficiente de variação experimental para caracteres de frutos de pimenteiras. Revista Ceres, v.58, n.2, 168171 ,

2011. http://www.ceres.ufv.br/ojs/index.php/ceres/article/view/ $\underline{3594}$

Singh, R. K.; Chaudhary, B. D. Biometrical methods in quantitative genetic analysis. New Delhi: Kalyani, 1979. 304p.

Stommel, J. R. Inheritance of fruit, foliar, and plant habit attributes in Capsicum. Journal of the American society for Horticultural Science, v.133, n.3, p.396-407, 2008. http://journal.ashspublications.org/content/133/3/396.full

Stommel, J. R.; Bosland, P. W. Ornamental pepper, Capsicum annuum. In: Anderson, N. (Ed.). Flower breeding and genetics: issues, challenges and opportunities for the 21 st Century. Dordrecht, The Netherlands: Springer, p.561-599, 2006. https://doi.org/10.1007/978-1-4020$\underline{4428-1 \_21}$

Streck, E. A.; Aguiar, G. A.; Júnior, A. M. M.; Facchinello, P. H. K.; Oliveira, A. C. Variabilidade fenotípica de genótipos de arroz irrigado via análise Multivariada. Revista Ciência Agronômica, v.48, n.1, p.101-109, 2017.

http://ccarevista.ufc.br/seer/index.php/ccarevista/article/vi ew/4392/1497

Viana, J. M. S.; Cruz, C. D.; Cardoso, A. A. Theory and analysis of partial diallel crosses. Genetics and Molecular Biology, v.22, n.4, p.591-599, 1999. http://dx.doi.org/10.1590/S1415$\underline{47571999000400021}$

Vivas, M.; Silveira, S. F.; Junior, A. T. A.; Cardoso, D. L.; Pereira, M. G. Herança da 
resistência do mamoeiro a doenças fúngicas com base em análise dialelica de Hayman.
Bragantia, v.72, n.4, p.332-337, 2013. http://dx.doi.org/10.1590/brag.2013.047 